\title{
FROM ENLIGHTENMENT UNIVERSALISM TO ROMANTIC NATIONALISM
}

\author{
MIHÁLY SZEGEDY-MASZÁK \\ Indiana University, Bloomington, IN, \\ USA
}

\begin{abstract}
"Tradition ist nichts, was Einer lernen kann, ist nicht ein Faden, den Einer aufnehmen kann, wenn es ihm gefällt; so wenig, wie es möglich ist, sich die eigenen Ahnen auszusuchen. Wer eine Tradition nicht hat und sie haben möchte, der ist wie ein unglücklich Verliebter." (Ludwig Wittgenstein) $^{1}$

"Der Sinn aller Tradition ist Konzentration des Seelischen. Das Wesen allen 'Fortschritts' ist Zertstreuung, Macht und damit Verlassen des eigenen Zentrums." (Wilhelm Furtwängler) ${ }^{2}$

"Das Überlieferte, das uns anspricht - der Text, das Werk, die Spurstellt selbst eine Frage und stellt damit unser Meinen ins Offene." (Hans-Georg Gadamer) $^{3}$

"(...) Mahler said that tradition is laziness, and I agree with him." (Pierre Boulez) ${ }^{4}$
\end{abstract}

\section{Imagined Communities}

As Benedict Anderson argues, a community can be called imagined if its members have a sense of belonging together even though they have no direct, personal knowledge of each other. ${ }^{5}$ This characterization applies to religious communities, the citizens of states, social classes, and nations. All of these are of historical nature. Except in states in which ruling dynasties play a role, in most imagined communities canonized texts and "great narratives" guarantee continuity. For Christians the Bible, for Moslems the Koran is the sacred book, for socialists the works of Marx and his disciples may constitute the core of the cultural canon. Most nations were defined in texts. The self-image of the Hungarians was at least partly created by Ferenc Kölcsey (1790-1838), the author of Hymn (1823), the text that became the national anthem after it was set to music by Ferenc Erkel in 1844. Four other works by Kölcsey, Zrinyi's Song (1830) and Zrinyi's Second Song (1838), two visionary poems predicting the death of the nation, and two longer essays, both published in 1826, Mohács, a meditation on the battle fought

Hungarian Studies 14/2 (2000)

0236-6568/2000/\$5.00 @ 2000 Akadémiai Kiadó, Budapest 
in 1526 that led to the partition of Hungary, and National Traditions, a work that is usually regarded as an early statement about the significance of folklore, have exerted a decisive influence on the interpretation of Hungarian identity. Since this last can be considered the most important contribution to the shaping of the Hungarian nation, I shall focus on this text.

Nation and class emerged after the dissolution of communities attached to religions and ruling dynasties. Homogeneous Christianity was so closely linked to the Latin language that the decline of monolingualism coincided with that of the unity of written culture. The authority of ruling dynasties suffered a serious blow with the executions of Charles I and Louis XVI. The idea that "workers have no fatherland of their own" was formulated as an antidote to nationalism and seemed to replace it at some stage. For the time being this prediction seems to have proven wrong. The distinction between ruling and oppressed classes can no longer hold in view of the growing stratification of societies. The prophecy implicit in the universalism of social utopia that nations would disappear in the near future has lost its credibility.

The cult of national character must be interpreted in the context of changing values. Although it would be misleading to sustain a monolithic vision of the Enlightenment, it is possible to suggest that some of its representatives saw a link between the perfectibility of man and the gradual move towards the unity of the human race. Paradoxically, the imperialism of the French revolution and the Napoleonic wars could be regarded as a logical consequence of the cosmopolitan dream about a universal society. Such technological inventions as Jean-Rodolphe Perronet's bridges or Mongolfier's baloons could suggest both the impracticableness and the growing dimensions of war.

For Count István Széchenyi, the founder of the Hungarian Academy, the goal was to imagine and create a nation. The attitude represented by the poet Kölcsey and his successor János Arany (1817-1882) was more ambiguous. For them tradition was partly to be established and partly to be discovered. Kölcsey was brought up on empiricist philosophy, and Arany lived in an age dominated by positivism. Both saw a link between tradition and oral culture.

What may be of lasting value in Kölcsey's approach is the observation that culture is not only a product of individual talent but also of a collective memory that is not a matter of personal choice. The validity of this argument seems to have been confirmed even by deconstruction criticism: "Those who do not study history are condemned to repeat it, though studying is also a form of repetition." 6

The starting hypothesis in Kölcsey's essay is that poetry represents the highest form of culture, and the highest form of poetry is "deeply rooted in national traditions" and "stands close to the nation." "In his view the perfect realization of this idea can be found in Homer. This assumption is based on two preconceptions: a) the definition of a national character has to be found in early history, b) orality is 
superior to writing. The first of these hypotheses has never ceased to affect Hungarian culture, although some historians suggest that it is not possible to speak of nations before the Enlightenment and the rise of the bourgeoisie. The second served as the basis for the institutionalization of folklore in the nineteenth century and seems to have a revival, especially among those who speak of a second(ary) or second-degree orality.

It is one of the inherent qualities of history that perceptions that appear dated in the short term may prove to be significant in the long run. An obvious example is the reading of Ossian offered in Kölcsey's essay. The premise that "the disappearance of tradition makes it impossible for us to develop an authentic interpretation of the characteristics of the past," 8 leads to the conclusion that "in a late phase of culture the ancient is given the features of the present age." "Other elements in the Hungarian Romantic's line of argument - the organicist view of national character, the emphasis on the capacity of the mother tongue to create reality or on cultural relativism - may be questioned, but the idea of the interdependence of past and present, of memory as a sine qua non of culture seems as valid as ever in the self-perception of nations.

The oppositions between exterior and interior, surface and depth, short-term and long-term processes suggest that the past is always rewritten by the everchanging present and raise the thorny question how influence or success is related to value.

A disciple of both the Enlightenment and Romanticism, Kölcsey was aware of what lay outside the domain of national traditions. He saw Christianity and science as supranational fields. Literature he thought to be their antidote. The idea of this duality of human culture continued to be influential in the twentieth century. In a book written in defence of small states, published in neutral Switzerland during World War II, Jan Huizinga described the humanist of Christianity and science as cosmopolitan: "Die Teilung in Nationen mußte ihm als ein die wahre Kultur störendes Hindernis vorkommen." 10

Today a similar gap exists between the international terminology of science and the language of the historians of national literatures. Generic concepts and periods differ according to linguistic areas and literary texts are still read as manifestations of national spirit.

\section{National Character}

In contrast to a view widely held, this concept was not born with Herder or the reaction against the wars fought by the French revolutionary army. The origins of counter-images can be traced back to earlier times. In Britain, for instance, a great number of articles were published with the aim of discrediting the Italian opera in 
the early 18th century. One could also refer to the self-contradictions of the Enlightenment, more specifically to some works of the author of Essai sur l'origine des languages and Considérations sur le gouvernement de Pologne (1772). The first among Jean-Jacques Rousseau's texts on national character dates from 1752. The comparison of organic and inorganic, familiar and alien, autonomous and imitative - closely reminiscent of Kölcsey's oppositions - is followed by the following observation:

Si j'étais chef de quelqu'un des peuples de la Nigritie, je déclare que je ferais élever sur la frontière du pays une potence où je ferais pendre sans rémission le premier Européen qui oserait y pénétrer, et le premier citoyen qui tenterait d'en sortir. ${ }^{11}$

Another relevant passage occurs in Du contrat social, published a decade later. Peter the Great is dismissed for imitating foreign models instead of letting national culture develop:

Pierre avait le génie imitatif; il n'avait pas le vrai génie, celui qui crée et fait tout de rien. (...) Il a d'abord voulu de faire des Allemands, des Anglais, quand il fallait commencer par faire des Russes; il a empêché ses sujets de jamais devenir ce qu'ils pourraient être, en les persuadant qu'ils étaient ce qu'ils ne sont pas. ${ }^{12}$

Rousseau's and Kölcsey's meditations on cultural universalism versus relativism have to be examined against the background of a wide-spread debate. No significant thinker was prone to extremist position. Universalists were not necessarily conservative; utopias were often based on the monolithic idea of one "Weltgeschichte." Relativism, on the other hand, frequently implied the preservation of existing values.

Rousseau's relativism may have been inspired by his reading of Montaigne and Montesquieu. It is also possible that the Swiss thinker formulated his ideas in reaction against the essay Of National Characters, published in 1748, in which David Hume considered "the Negroes to be naturally inferior to the Whites," on the ground that they did not display "any symptom of ingenuity,"13 in other words, they could not develop a culture of their own.

Although in most cases national character was created in texts, it would be a mistake to ignore other factors. The evidence offered by the history of visual arts is summarized by a recent work in the following manner: "The growing numbers of accessible international collections and the availability of prints from all over Europe allowed eighteenth-century artists of even the most mediocre fortunes to build up a cosmopolitan visual imagination. This, combined with the decline of the tradition of regional workshop training, established a social environment which, in general terms, did not favour the natural production of idiosyncratic regional 
styles of production. Increasingly, therefore, national and regional artistic character had actively to be invented or re-established in the wake of vigorous political campaigns to assert national identity. Being the artist of a certain locality or nation increasingly became a matter of choice rather than accident of birth." ${ }^{14}$ In his Treatise on Ancient Painting (1740) George Turnbull argued that "the general and national Character of a People may be conjectured from the State of the Arts amongst them: and reciprocally". ${ }^{15}$ From Jacques-Louis David's early The Oath of the Horatii (1784-5, Musée du Louvre) to Caspar David Friedrich's painting known as The Stages of Life or The Three Ages of Man (1834-5, Museum der Bildenden Künste, Leipzig) many works of art can be seen as the visual illustrations of the parallel between the cycle of the life of an individual and that of a nation. The belief that culture developed cyclically from a state of youthfulness towards maturity, old age, and death was supported by the cult of ruins.

Kölcsey was well-versed in the philosophy of the French Enlightenment, so the opening words of his essay have to be read in the context of the ideas on cultural universalism and realitivism formulated by such authors as Montesquieu, Voltaire, Buffon, Rousseau, Diderot, Condillac, Helvétius, and Condorcet:

\section{Nations have the same phases in their life as individuals. Their child- hood is followed first by the promises of youth and later by the strength of maturity, which, in turn, is replaced by the decline of old age. ${ }^{16}$}

This old topos, inherited from Classical Antiquity, gained special significance in the late eighteenth and early nineteenth century. Széchenyi used it inconsistently, which today may appear more acceptable than Kölcsey's blunt statement, although it has to be admitted than many national literary histories seem to comply with an explicit teleology similar to the one underlying Kölcsey's work.

In marked contrast to Kölcsey and many others, Széchenyi often toyed with the idea that national character has to be created in writing. Innumerable fragments from his works were given a proverbial status by later generations and the closing sentence of Credit (1830), his most influential book - "Many think: Hungary h a s b e e n; I like to believe she w i 11 b e"17 - served as a slogan in what is still called the Age of Reform, the period between Waterloo and the revolutions of 1848 .

As a diary entry dated 7 April 1819 indicates, the source of Széchenyi's ideas on national character was A Classical Tour Through Italy in 1802 by John Chetwoode Eustace, published in four volumes in London, in 1815. The quotation from this work starts with the following words:

National character, though it may be influenced both by the will and the climate, is not the effect of either. Government and education, are the grand and efficient causes in the formation of character both public and private. ${ }^{18}$ 
A month later Széchenyi made the following remark:

Eine Nation entstehet ebenso wie ein Kind geboren wird - gehet durch die Jahre der Adolescens, der Jugend, der Mannheit, und des Alters - und stirbt endlich ab - der einzige Unterschied nach der Tode einer Nation und eines Menschen ist nur, dass der Leichnahm eines Menschen von Würmern gefressen wird, und zu sein gänzlich aufhört, indessen der verlebte Körper einer Nation - lange Jahre noch fortvegetirt -. Ob eine Nation gross werden oder unbedeutend bleiben soll, hengt von dem Zufall eben so sehr ab, als von der Erziehung die es in seinen Kinder Jahren bekommen hat. ${ }^{19}$

Since Széchenyi's diaries were not published until much later, it is not likely that Kölcsey had access to them. Széchenyi, however, could rely on the poet's essay when later he blamed Hungarians for the preservation of the outmoded and for superficial imitation: "We have no national habits; our existence and knowledge depend on imitation. Unlike other nations, we stick to the old and are superficial in imitating others. ${ }^{20}$

Are the characteristics of the Hungarian nation to be preserved or to be created? The main reason for Széchenyi's great influence on both conservatives and liberals is his inconsistency in answering that question. "Hungary is an old fortress that needs restoration." One page after this statement quite a different tone is set by the following remark: "The Hungarian is but a child. He has not achieved anything yet but the psychic and physical energy hidden in his young soul may enable him to do great things." ${ }^{21}$ When defining the character the Hungarian nation should acquire in the future, he resorts to the figure of speech known as oxymoron: "Our country needs an old head attached to young shoulders". ${ }^{22}$ The paradoxical nature of the combination of tradition and innovation suggests not only a compulsion to fuse contradictory experience into a unity but also the possible disappearance of national character. His declaration made in the Upper House, on 2 October 1844, refers to the second alternative:

It may be possible that those who will replace us will be more honest and intelligent, but I take it for certain that they will not be Hungarians. ${ }^{23}$

Throughout his life Széchenyi viewed national character as the product of literature. Here is a passage of a work entitled Dust and Mud, written on 13 June 1858:

If in youth an individual or nation had nothing similar to what mortals could never express but Schiller, Alfieri, Moore, Berzsenyi, Vörösmarty, and others suggested, that nation would sink to the level of a machine and may achieve material but no spiritual prosperity. ${ }^{24}$ 
A similar contrast of organic and inorganic, coupled with the idea of the different ages of nations, can be found in the works of numerous French authors. Several texts by Taine, L'avenir de la science (written in 1848) and De l'origine $d u$ langage (written between 1848 and 1858) by Renan, or Gobineau's notorious Essai sur l'inégalité des races humaines (written between 1853 and 1855) could be mentioned in this context. ${ }^{25}$

The last of these works may illustrate the damage theories about the diversity of human communities have done to human culture. Yet it cannot be denied that the preconception concerning the ages of nations sometimes went together with tolerance toward alterity - as the examples of Spengler, Toynbee, Berdyaev, Valéry, and Wittgenstein indicate. The traces of the same conception can also be found in the debates over the explanation of the end of the Habsburg Monarchy or in the revival that makes Spengler an early critic of Eurocentrism. ${ }^{26}$

In view of the international survival of the organicist interpretation of history, it cannot be called anachronistic that the questions raised by Kölcsey and Széchenyi continued to tempt Hungarian writers until the present day. Here I have no space for a summary of these later developments. ${ }^{27}$ In the rest of this essay my intention is to focus on an issue that preoccupied virtually all the interpreters of Kölcsey's text: to what extent have texts to be evaluated on the basis of their contribution to the shaping of national character.

\section{The Driving Forces of Development: Originality, Language, and the Future}

"In the age of public education the brilliance of individual greatness is more sporadic and less spectacular." 28 This statement may echo Émile and Über naive und sentimentalische Dichtung. It also reveals the ambiguity of Kölcsey's approach to progress: on the one hand, it seems an organic process, on the other, it leads from the natural to the artificial.

The duality of imagination and learning was a cliché throughout the nineteenth century. The double meaning of "original" implied that the specificity of a culture has to be discovered in early history. The fundamental question for Kölcsey was whether the early legacy of the Hungarian people was sufficient for the survival of their culture. He clearly saw that distance was a source of alienation. At the same time, the Greek example convinced him that the greatness of a culture consisted in its capacity to recognize itself in the other. No culture could do without foreign influence, yet imitation was a sign of the weakness of native traditions.

The language reform supported by Kölcsey represented a compromise between the legacy of the Enlightenment and the Romantic approach to language: it as- 
serted the claims of the vernacular, yet it aimed at creating a standard "polished" idiom, purged of all signs of local dialect.

One of the reasons why Kölcsey's essay National Traditions could serve as a starting-point for so many and so different interpretations is that its message is rather ambivalent. Culture is both influence and self-reliance. On the one hand, it seems to suggest that the significance of a culture depends on its ability to make an impact on others; on the other hand, it draws a distinction between two relations between self and other: imitation and appropriation. Not all foreign occupations are viewed in the same way: the Arab settlers of Spain are said to have created a culture of their own, whereas the Ottoman Turks are harshly criticized for destroying the civilization of the peoples they conquered. A similar duality is ascribed to the oppressed: appropriation is contrasted with servile imitation.

The ideal of Greek Antiquity is upheld to exclude one extreme, that of unlimited cultural relativism. The other extreme would be the utopia of one mankind and one history. In recent years a similar critique of these two attitudes was formulated by Paul Ricoeur, who condemned both the racist interpretation of history and the belief in the unity of Weltgeschichte, the globalizing force of the American way of life that leaves no room for a dialogue with the histories of the different parts of the world. ${ }^{29}$

One of the possible readings of Kölcsey's essay was given by Mihály Babits (1883-1941), an outstanding poet and the author of two seminal discursive works, the long essay Hungarian Literature (1913) and its counterpart A History of European Literature (published in Hungarian in 1934-35 and in German translation in 1949). If Kölcsey's essay is viewed from the perspective outlined in these two works, its message is that the development of a culture depends not only on its unity but also on the multiplicity of the tasks it can handle, so that the main goal a nation has to reach is dialogue with other cultures. To preserve one's identity is linked to tolerance towards others. Kölcsey's emphasis on "influence" implies that a familiarity with the other is a precondition of culture. "I am another" also means "the other is myself." Culture is mediation and so depends on our ability to keep a distance from our own community and assimilate the alien. The duality of self and other need not cause schizophrenia, although it may not exclude opposition or conflict.

If read from the perspective of Romanticism, National Traditions marks a shift from the preconception that a) traditional rural culture was a barbarity to be forgotten, and b) the primary task for the national community was to absorb the culture of the other parts of Europe. After the universalist teleology of some Enlightenment thinkers committed to the task of dragging Hungarians out of a barbarous rustic dark age and towards a bright cosmopolitan future had been rejected, artists and writers created an ideology based on the notion that Hungary represented a unique cultural entity that had grown out of a distinctive landscape. 
In the $1840 \mathrm{~s}$, in the works of Petoffi and others, the untrammelled plainland, the "puszta" became an icon of national identity. Such long epic poems as The Flight of Zalán (1825) by Vörösmarty or The Death of Buda (1863) by János Arany expressed a deep, consecrating sense of belonging to one's own land and folk. It was at least partly due to Kölcsey's influence that in the nineteenth century some Hungarian writers regarded literature as a moral force to preserve the decorum of a national community threatened by cosmopolitan positivists.

Undeniably, it is also possible to make a more destructive interpretation of Kölcsey's essay. "What is national character? Bad habits." This categorical condemnation by Imre Madách (1823-1864), the author of The Tragedy of Man, ${ }^{30}$ a 4117-line-long dramatic poem on the history of mankind that contains no more than a single reference to Hungarian history - foreshadows Nietsche's association of decline with parochialism and the ossification of national character:

\begin{abstract}
Wenn nämlich ein Volk vorwärts geht und wächst, so sprengt es jedesmal den Gürtel, der ihm bis dahin sein nationales Ansehen gab; bleibt es stehen, verkümmert es, so schließt sich ein neuer Gürtel um seine Seele; die immer härter werdende Kruste baut gleichsam ein Gefängnis herum, dessen Mauern immer wachsen. Hat ein Volk also sehr viel Festes, so ist dies ein Beweis, daß es versteinern will und ganz und gar Monument werden möchte: wie es von einem bestimmten Zeitpunkte an das Ägyptertum war. ${ }^{31}$
\end{abstract}

If the identity of a nation becomes easily recognizable, the next stage is the loss of that identity.

Ein historisches Phänomen, rein und vollständig erkannt und in ein Erkenntnisphenomän aufgelöst, ist für den, der es erkannt hat, tot. ${ }^{32}$

Although Kölcsey's essay contains no such explicit prediction, it does not exclude the disappearance of nations in a more distant future. More than a century after the publication of National Traditions, in 1939 a collection of essays appeared with the title What Is Hungarian? Edited by the historian Gyula Szekfü, this book was meant to suggest that the concept of national character had lost its validity by the twentieth century. As in so many other cases, the counter-identity of Germans supplied the background. What counted as a brave dismissal of racist theories at the time of the threat of Nazi Germany may be interpreted in a somewhat different way in 2000. It seems rather paradoxical that a historian made the following sweeping generalization:

People are everywhere, in every period, season, and climate the same; the same laws of life make them weep, laugh, relax, join groups, and kill each other. ${ }^{33}$ 
While such a statement resembles the clichés of rationalistic universalism propounded by rather ahistorical representatives of the Enlightenment, the claims made by the poet Babits and the composer Kodály, suggesting that Hungarians take no interest in metaphysics and "labirinthine" complexity in art, appear of rather doubtful value. More relevant might be the point made by the Protestant bishop László Ravasz that

there is no objetctive feature that could be considered to be a canonical measuring rod, an unambiguously Hungarian characteristic in literature or in the arts. ${ }^{34}$

Such a negative definition is compatible with the view that a national community can be defined only in linguistic terms. The idea that being Hungarian means using the conceptual map constituted by the Hungarian language is by no means absent from Kölcsey's essay. "Hungarians can achieve originality by the use of their language," ${ }^{\prime} 35$ the poet writes, lamenting that in the age of the rise of poetry composed in the vernacular, Janus Pannonius (1434-1472) "used a Roman lute when singing fine, yet foreign songs." 36 The opposition between the written language of the Latin Antiquity and Middle Ages on the one hand and the constantly changing, spoken vernacular tradition handed down by word of mouth on the other, is related to the debate mentioned earlier: "the defenders of writing were inclined to universalism, whereas the adherents of orality preferred relativism." ${ }^{37}$

Put another way, it is possible to read National Traditions with the eyes of Dezső Kosztolányi (1885-1936), the most important exponent of a language-based cultural relativism in twentieth-century Hungarian literature. Understandably, this poet relied on Széchenyi's numerous works rather than on Kölcsey's essay. The idea than human consciousness is inseparable from language, implicit in Kölcsey's line of argument, was more consistently expressed by Széchenyi, who was convinced that the disappearance of even the tiniest linguistic community was an irreparable loss to mankind. "I have received my language from God and I will return it to Him upon my death." This declaration, made in the Upper House on 30 November $1835,{ }^{38}$ is symptomatic of the attitude Kosztolányi attributed to Széchenyi in his To Be or Not to Be (1930). This long essay is a counterpart of Hungarian Literature by Babits. Babits urged his reader to look at his/her culture with the eyes of an outsider. Kosztolányi's point is that a native reader can never keep that distance from his/her own literature. In that sense the gap between the self and the other cannot be bridged.

The idea that speaking a mother tongue means having preconceptions is more explicitly stated by Széchenyi but can also be detected in Kölcsey's text. Hungarian literature is the legacy of the language, taking language in a rather broad sense as the historical memory, belief system, and way of life of an imagined 
FROM ENLIGHTENMENT UNIVERSALISM TO ROMANTIC NATIONALISM 191

community. Irrespective of the possible disappearance of nations as imagined communities in the future, this language-based conception may be the most obvious manifestation of the role of texts in shaping national identity.

\section{Notes}

1. Ludwig Wittgenstein, Vermischte Bemerkungen (Chicago: The University of Chicago Press, 1984) 76.

2. Wilhelm Furtwängler, Aufzeichnungen 1924-1954 (Wisbeaden: F. A. Brockhaus, 1980) 264.

3. Hans-Georg Gadamer, Wahrheit und Methode: Grundzüge einer philosophischen Hermeneutik (Tübingen: S. J. C: B: Mohr (Paul Siebeck), 1986) 379.

4. Pierre Boulez, "History in the Present Tense," CD Review, December 1990, 23.

5. See Benedict Anderson, Imagined Communities (London: Verso, 1983).

6. J. Hillis Miller, Reading Narrative (Norman: University of Oklahoma Press, 1998) 3.

7. Ferenc Kölcsey, Nemzeti hagyományok (Budapest: Szépirodalmi Könyvkiadó, 1950) Vol. I, 505506.

8. Kölcsey, Ibid., 513.

9. Kölcsey, Ibid., 514.

10. J. Huizinga, Im Bann der Geschichte: Betrachtungen und Gestaltungen (Burg: Burg-Verlag, 1943) 162.

11. Jean-Jacques Rousseau, Discours sur les arts et les sciences - Discours sur l'origine de l'inégalité (Paris: Garnier-Flammarion, 1971) 117.

12. Jean-Jacques Rousseau, Du contrat social (Paris: Gernier-Flammarion, 1966) 82.

13. David Hume, Essays: Moral, Political and Literary (London: Oxford University Press, 1971) 213.

14. Matthew Craske, Art in Europe 1700-1830: A History of the Visual Arts in an Era of Unprecedented Urban Economic Growth (Oxford University Press, 1997) 110.

15. Quoted by Matthew Craske in Art in Europe 1700-1830, 24.

16. Kölcsey, Ibid., 490.

17. István Széchenyi, Hitel (Budapest: Magyar Történelmi Társulat, 1930) 492.

18. Gróf Széchenyi István Naplói. Vol. I (Budapest: Magyar Történelmi Társulat, 1825) 577.

19. Gróf Széchenyi István Naplói, Vol. I, 629.

20. István Széchenyi, Világ vagy is felvilágositó töredékek némi hiba 's előitélet eligazitására (Pest: Füskúti Landerer, 1831) 72.

21. Széchenyi, Világ, 101-102, 103.

22. Széchenyi, Világ, XXIX.

23. Gróf Széchenyi István Beszédei (Budapest: Athenaeum, 1887) 358.

24. Gróf Széchenyi István Döblingi Hagyatéka, Vol. III (Budapest: Magyar Történelmi Társulat, 1925) 862-863.

25. See Tzvetan Todorov, Nous et les autres: La réflexion française sur le diversité humaine (Paris, 1989) $154,174$.

26. See, for instance, Mireille Marc-Lipiansky, "Crise ou déclin de l'Occident?" L'Europe en formation 306-307, automne - hiver 1997, 47-79.

27. See my essay “A Nemzeti hagyományok korszerüsége,” Valóság 1999/5, esp. 36-38.

28. Kölcsey, Ibid., 492. 
29. Paul Ricoeur, Histoire et vérité. Troisième édition augmentée de quelques textes (Paris: Seuil, 1964) 185

30. Madách Imre Össszes Müvei (Budapest: Révai, 1942) Vol. II, 757.

31. Friedrich Nietzsche, Menschliches, Allzumenschliches: Ein Buch für freie Geister (Wilhelm Goldmann, 1981) 412.

32. Friedrich Nietzsche, Unzeitgemäße Betrachtungen (Frankfurt am Main: Insel, 1981) 106.

33. Gyula Szekfü (ed.), Mi a magyar? (Budapest: Magyar Szemle, 1939) 489.

34. Gyula Szekfü (ed.), Mi a magyar? 32.

35. Kölcsey, Ibid., 508.

36. Kölcsey, Ibid., 515.

37. Katalin Neumer, Gondolkodás, beszéd, írás (Budapest: Kávé, 1998) 38.

38. Széchenyi István Válogatott Müvei (Budapest: Szépirodalmi, 1991) Vol. I, 692. 